\title{
Dependence of Antitumor Activity on the Electrophilicity of 2-Substituted 1,4-Naphthoquinone Derivatives
}

\author{
Yongseog Chung, Jikang Yoo, Si-Hyun Park, ${ }^{\ddagger}$ Bok Hee Kim, ${ }^{\ddagger}$ Xi Chen, ${ }^{\#}$ Chang-Guo Zhan,." and Hoon Cho \\ Department of Polmer Science \& Engineering, Chosun Lniversitw, Gwangin 501-759, Korea. E-mail: hchoachosun ackr \\ - Department of Chemistry, BITRC, Institute for Basic Science, Chungbuk National Lniversity, Chungbuk 361-763, Korea \\ "Department of Photonic Engineering. Chosth Chimersitw, Gu'angit 501-759, Korea \\ sDepartment of Food Science and Nutrition, Chosun Lniversity, Gn'angit 501-759, Korea \\ "Deparment of Pharmacettical Sciences, College of Pharmacy, Lniversitw of Kentucky, Lexington, KY 40536-0082, L.S.A. \\ E-mail: zhanciukvedu \\ Received January 8, 2007
}

Key Words : Naphthoquinone. Cỵtotoxicity. Antitumor activity. Electrophilicity

Naphthoquinones are widely distributed in nature and have been used for centuries in home remedies as well as in cosmetics. Many clinically important antitumor drugs containing quinone nucleus, such as anthracyclines. mitoxantrones and saintopin. show excellent anticancer activity. These anticancer agents are effective inhibitors of DNA topoisomerase. and it is understood that the cytotoxicity of quinone analogues results from the inhibition of DNA topoisomerase II. ${ }^{1.4}$ 1.4-Naphthoquinone derivatives have also been shown to inhibit human DNA topoisomerase I. ${ }^{\$ 11}$ Furthermore, they can induce the fornation of the semiquinone radical, which can transfer an electron to oxygen to produce superoxide. This process is catalyzed by flavoenzymes such as NADPH-cytochrome-P-450 reductase. Both superoxide and seniquinone radical anions of naphthoquinone analogues can generate the hydroxyl radical, which is known to cause DNA strand breaks. ${ }^{1.14}$ In addition, a number of 1,4-naphthoquinone derivatives have been found to possess powerful pharmacological effects such as antibacterial. ${ }^{15,16}$ antifungal. ${ }^{15.18}$ anti-inflammatory. ${ }^{18.22}$ antithrombotic. $^{23.24}$ antiplatelet. ${ }^{19.55}$ antiviral. $^{23 . \pm 5}$ antiallergic, ${ }^{26}$

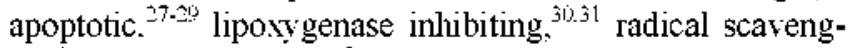
ing $^{6}$ and antiringworm ${ }^{15}$ activities. Previously we reported that 6-substituted 5.8-dimethosy-1,4-naphthoquinone derivatives exhibited higher antitumor activity than 2 -substituted 5.8-dimethoxy-1,4-naphthoquinone. It was suggested that the $\mathrm{C} 2$ or $\mathrm{C} 3$ of 6 -substituted compounds are better Michaeltype acceptor than the $\mathrm{C} 3$ of 2 -substituted compounds and are attacked more easily by nucleoplules such as amine or thiol functional groups in the cells. ${ }^{33-36}$ We also reported that a compound having a higher ${ }^{\mathrm{H}} \mathrm{H}-\mathrm{NMR}$ chemical shift at the $\mathrm{C} 3-\mathrm{H}\left(\delta_{\mathrm{H}}\right)$ usually should exhibit a lower $\mathrm{ED}_{50}$ value. ${ }^{35} \mathrm{In}$ the present paper, a series of new 5.8-dimethosy - 1,4-naphthoquinone (DMNQ) and 5.8-dihydroxy-1.4-naphthoquinone (DHNQ) derivatives were synthesized. their net atomic charge of $\mathrm{C} 3$ in the quinoid moiety was obtained from the natural population analysis of the molecular orbitals calculated at the $\mathrm{HF} / 6-31 \mathrm{G}^{*}$ level, and their cytotoxicity against L1210 and P388 cancer cells was examined. The antitumor action was also assessed in mice bearing $S-180$ cells in the peritoneal cavity.

\section{Results and Discussion}

We synthesized new 2-substituted DMNQ and DHNQ derivatives and measured the net atomic charge of C. 3 in the<smiles>COc1ccc(OC)c2c1C(=O)C(CN(C)c1nc3c(C)cccc3s1)C2=O</smiles><smiles>Cc1cccc2sc(N(C)CC3=CC(=O)c4c(O)ccc(O)c4C3=O)nc12</smiles><smiles>COc1ccc(OC)c2c1C(=O)C=C(CN(C(=O)CCC(=O)O)c1nc3c(C)cccc3s1)C2=O</smiles><smiles>Cc1cccc2sc(N(CC3=CC(=O)c4c(O)ccc(O)c4C3=O)C(=O)CCC(=O)O)nc12</smiles><smiles>COc1ccc(OC)c2c1C(=O)C=C(CNc1ccc(NC(=O)CCC(=O)O)c(C(F)(F)F)c1)C2=O</smiles><smiles>O=C(O)CCC(=O)Nc1ccc(NCC2=CC(=O)c3c(O)ccc(O)c3C2=O)cc1C(F)(F)F</smiles>

Figure 1. Structures of 5,8-dimethoxy-1,4-naphthoquinone analogs and 5,8-dihydroxy-1,4-naphthoquinone analogs. 
<smiles>COc1ccc(OC)c2c(OC)c(C=O)cc(OC)c12</smiles><smiles>Cc1cccc2sc(N(C)CC3=CC(=O)c4c(O)ccc(O)c4C3=O)nc12</smiles><smiles>COc1ccc(OC)c2c(OC)c(/C=N/c3nc4c(C)cccc4s3)cc(OC)c12</smiles><smiles>COc1ccc(OC)c2c(OC)c(CNc3nc4c(C)cccc4s3)cc(OC)c12</smiles><smiles>COc1ccc(OC)c2c1C(=O)C=C(CN(C)c1nc3c(C)cccc3s1)C2=O</smiles><smiles>CC#N</smiles><smiles>COc1ccc(OC)c2c(OC)c(CN(C)c3nc4c(C)cccc4s3)cc(OC)c12</smiles>

Scheme 1

quinoid moiety from the natural population analysis of the molecular orbitals calculated at the $\mathrm{HF} / 6-31 \mathrm{G}^{*}$ level and the chemical shift $\left(\delta_{\mathrm{H}}\right)$ of $3-\mathrm{H}$ from NMR analysis. DMNQ and DHNQ derivatives. shown in Figure 1, were șynthesized as described in a previous report. ${ }^{36}$ The starting compound. 2 . formy ltetramethoxy'naphthalene (1) was prepared from 1.5 dihydroxynaphthalene through 4-step reactions of methylation $(86 \%)$, bromination $(85 \%)$. methoxylation $(61 \%)$, and formylation (96\%) ${ }^{37}$ The reaction of 2-formyltetramethoxynaphthalene (1) with hydroxylamine afforded 2-(hydroxyiminomethyl)-1.4.5.8-tetramethoxy'naphthalene (11). which was then alkylated to obtain the desired 2-(alkoxyiminomethyl)-1.4.5.8-tetramethoxynaphthalene derivatives (1214). The derivatives of 2-(alkoxyiminomethyl)-5.8-dimethoxy-1 4-naphthoquinone (15-17) were prepared from compounds 12-14 by oxidation with ammonium cerium (IV) nitrate and the resulting compounds were conjugated with glutathione (GSH), to produce 2-(alkoxyiminomethyl)-3gluthathiony 1-5,8-dimethoxy-1.4-naphthoquinone derivatives (18-20), respectively. Compounds 5. 7 and 9 were obtained by the oxidation of the corresponding 2-substituted 1.4.5.8tetramethoxynaphthalenes with cerium (IV) ammonium nitrate (CAN). followed by demethylation with $\mathrm{AlCl}_{\hat{3}}$ and $\mathrm{HCl}$ to provide compounds 6.8 and 10 (Scheme 1). Overall
Table 1. Correlation of cytotoxicity and antitumor activity with the atomic charge and $\delta_{\mathrm{H}}$ of the C-3 position of DMNQ and DHNQ derivatives

\begin{tabular}{|c|c|c|c|c|c|}
\hline \multirow{2}{*}{$\begin{array}{l}\text { No. of } \\
\text { Compd. }\end{array}$} & \multicolumn{2}{|c|}{$E D_{50}(\mu g / m L)$} & \multirow{2}{*}{$\begin{array}{l}\mathrm{T} / \mathrm{C} \\
(\%)\end{array}$} & \multirow{2}{*}{$\begin{array}{c}\text { atomic charge } \\
\text { of } \mathrm{C}^{3}\end{array}$} & \multirow{2}{*}{$\hat{H}_{\mathrm{H}}$ of $3-\mathrm{H}$} \\
\hline & $\mathrm{L} 1210$ & P388 & & & \\
\hline 5 & 1.21 & 0.56 & 214 & -0.275 & 675 \\
\hline 6 & 0.45 & 0.26 & 257 & -0.252 & 6.99 \\
\hline 7 & 4.76 & 4.19 & 105 & -0.328 & 6.34 \\
\hline 8 & 0.34 & 0.18 & 331 & -0.243 & 7.37 \\
\hline 9 & 8.92 & 40.41 & 101 & -0.250 & 6.66 \\
\hline 10 & 1.57 & 1.64 & 240 & -0.238 & 7.01 \\
\hline Adriamycin & 0.07 & 0.14 & 234 & & \\
\hline
\end{tabular}

yields ranged from $60 \%$ to $80 \%$.

The cytotoxicity of naphthoquinone derivatives was measured against L1210 (Lymphocytic leukemia) and P388 (Lymphoid neoplasma) cancer cell lines using the MTT colorimetric method. ${ }^{38}$ The $\mathrm{ED}_{50}$ value $(\mu \mathrm{g} / \mathrm{mL})$ was defined as the concentration of compound which produced a $50 \%$ reduction in viability relative to the control in three independent experiments. In comparison with DMNQ derivatives $(5,7,9)$, interestingly. DHNQ derivatives $(6,8,10)$ exhibited higher cy totoxic activity against L1210 and P388. The DHNQ

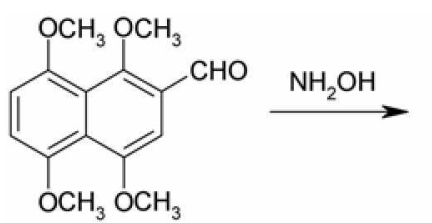<smiles>[R1]CC1CC1</smiles>

11<smiles>[R]ON=Cc1cc(OC)c2c(OC)ccc(OC)c2c1OC</smiles>

12-14<smiles>[R]ON=CC1=CC(=O)c2c(OC)cc(OC)c(OC)c2C1=O</smiles>

15-17

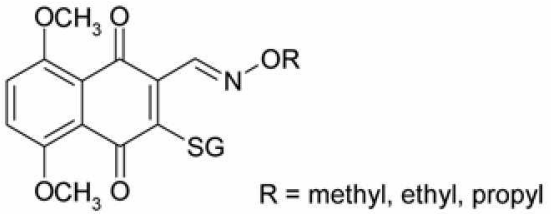

18-20

Scheme 2 
Table 2. Cytotoxicity of DMNQ derivatives with and without glutathione at the $\mathrm{C}-3$ position

\begin{tabular}{cccccccc}
\hline \multirow{2}{*}{$\begin{array}{c}\text { No. of } \\
\text { Compd. }\end{array}$} & R & \multicolumn{7}{c}{ ED } & & & L1210 & P38 $(\mathrm{tg} / \mathrm{mL})$ & HL-60 & A549 & SNU-I & Vero \\
\hline $\mathbf{1 5}$ & Methyl & 4.97 & 2.24 & 1.26 & 56.42 & 11.82 & 41.37 \\
$\mathbf{1 6}$ & Ethyl & 5.10 & 2.29 & 2.17 & 61.18 & 10.76 & 45.04 \\
$\mathbf{1 7}$ & Propyl & 5.28 & 2.76 & 2.03 & 48.06 & 19.14 & 51.29 \\
$\mathbf{1 8}$ & Methyl & - & - & - & - & - & - \\
$\mathbf{1 9}$ & Ethyl & - & - & - & - & - & - \\
$\mathbf{2 0}$ & Propyl & - & - & - & - & - & - \\
\hline
\end{tabular}

-, no activity:

showed better antitumor activity than DMNQ in mice bearing S-180 cells in the peritoneal cavity (Table 1).

From a toxicological perspective quinones possess two principal chemical properties that confer their reactivity in biological systems: they are electrophiles and oxidants. Quinones are Michael acceptors. and cellular damage can occur through alkylation of crucial cellular proteins and/or DNA. Alternatively. quinones are highly redox active molecules which can redox cycle with their semiquinone radicals. leading to the formation of reactive oxygen species. including superoxide. hydrogen peroxide and ultimately the hydroxyl radical ${ }^{39}$ In an attempt to elucidate the electrophilic effect of DMNQ the C3 position of DMNQ was protected by alkylation of glutathione (GSH) (Scheme 2) and the cytotoxicity was measured against L1210. P388. HL-60. A549. SNU-1 cancer cell lines and nomal Vero cells. Although the GSH-bound DMNQ (compounds 18-20) may' still retain the ability to redox cycle alkylation of the $\mathrm{C} 3$ position of DMNQ by GSH rendered the compounds totally inactive (Table 2). Thus the biological activity of naphthoquinone derivatives is believed to be dependent upon the electrophilicity of the quinone moiety. We also demethylated the 5.8-dimethoxy groups to produce DHNQ and cytotoxic activity against L1210 and P388 cancer cells was examined. The antitumor action was also assessed in mice bearing S180 cells in the peritoneal cavity. Interestingly removal of the methyl groups of the 5.8-dimethoxy' groups significantly' increased both bioactivities.

As shown in Table 1. removal of the methyl groups of 5.8dimethoxy-1.4-naphthoquinone (DMNQ). which produced 5.8-dilydroxy-1.4-naphthoquinone (DHNQ). increased the chemical shift $\left(\delta_{\mathrm{H}}\right)$ of $3-\mathrm{H}$ from 6.75 .6 .34 and 6.66 to 6.99 . 7.37 and 7.07 . respectively. suggesting that the antitumor activity of DHNQ is greater than that of DMNQ. The natural population analysis of the molecular orbitals calculated at the $\mathrm{HF} / 6-31 \mathrm{G}^{*}$ level also showed that the electron charge of C.3 in DHNQ was decreased more than that in DMNQ, suggesting that the antitumor activity of DHNQ is greater than that of DMNQ. As anticipated. Compound 8. which had a higher electrophilicity in the C3 position. demonstrated better antitumor activity than the others did. The lower antitumor activity of compound 7 could be also ascribed to the lower electrophilicity at the $\mathrm{C} 3$ position of the compound.

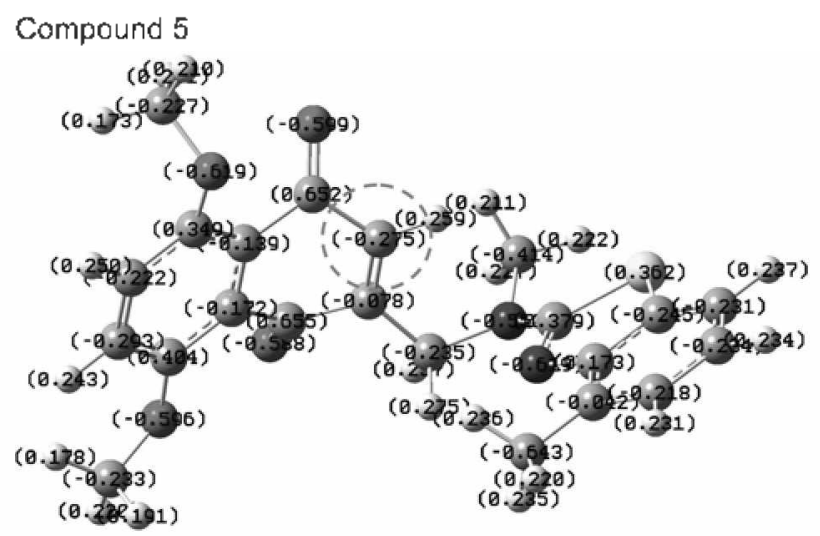

Compound 6

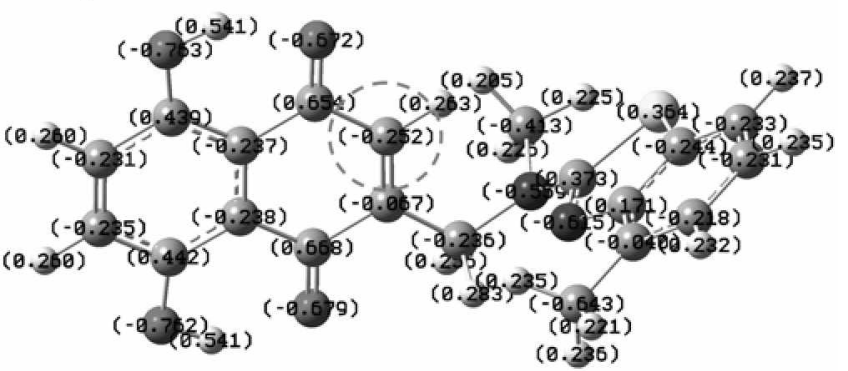

Figure 2. Optimized geometries of compounds 5 and 6 , in which the net atomic charges were obtained from the natural population analysis of the molecular orbitals calculated at the $\mathrm{H} F / 6-3 \mathrm{IG}^{-}$ level.

\section{Experimental Section}

In vitro cytotoxicity (MTT Assay). Target cancer cells were suspended at $2 \times 10^{5}$ cells $/ \mathrm{mL}$ in medium ( $10 \%$ fetal bovine serum) containing various concentration of sy'nthesized naphthoquinone derivatives and vigorously vortexed. after which $100 \mu \mathrm{L}$ aliquots were dispensed into 96-well. flat-bottomed microtiter plates using a multichannel pipette Plates were then incubated at $37^{\circ} \mathrm{C}$ for $72 \mathrm{~h}$ in a $5 \% \mathrm{CO}_{2}$ incubator. MTT [3-(4,5-dimethylthiazol-2-yl)-2,5-diphenyl tetrazolium bromide] was dissolved in PBS at $5 \mathrm{mg} / \mathrm{mL}$ and filtered to sterilize and remove a small amount of insoluble residue present in MTT batches. An aliquot of $10 \mu \mathrm{L}$ of MTT stock solution was added to each well using a multichannel pipette and the plate was incubated at $37^{\circ} \mathrm{C}$ for $4 \mathrm{~h}$. To each well. $150 \mu \mathrm{L}$ of $0.01 \mathrm{~N} \mathrm{HCl}$ solution containing $10 \%$ sodium dodecyl sulfate was added to solubilize the MTT formazan. Plates were gently shaken until all formazan crystals were dissolved. and the absorbance at $540 \mathrm{~nm}$ was determined with a Microplate Reader (SPECTRA MAX 340). All results were corrected for background absorbance detected in wells without added MTT. Preliminary experiments showed a linear relationship between the cell numbers and the absorbance at $540 \mathrm{~nm}$, when cells in the range of $4 \times$ $10^{2}$ to $4 \times 10^{5}$ per well were examined.

In vivo antitumor activity in ICR mice bearing S-180 cells. The test samples dissolved in saline. including $2 \%$ DMSO and $4 \%$ Tween 80 . were stored at $4{ }^{\circ} \mathrm{C}$. S- 180 cells 
$\left(0.1 \mathrm{~mL}\right.$ per mouse) suspended in saline $\left(1 \times 10^{7}\right.$ cells $\left./ \mathrm{mL}\right)$ were inoculated intraperitoneally to male ICR mice. Twentyfour hours after the transplantation. the mice were divided into groups of 8 mice. The test compounds were administered daily into the intraperitoneal cavity of the mice for 5 days. The rate of growth inhibition (T/C.\%) was calculated by the following equation:

$$
\begin{aligned}
& \mathrm{T} / \mathrm{C}(\%)= \\
& \text { Average survival period in the test group } \\
& \text { Average survival period in the control group } \times 100
\end{aligned}
$$

Computational methods. The molecular geometries were fully' optimized by performing PM3 calculations. The optimized geometries were used to carry out $a b$ initio molecular orbital calculations by using the Hartree-Fock (HF) theory' with $6-31 \mathrm{G}^{*}$ basis set. ${ }^{\text {at }}$ All of these electronic structure calculations were performed by using the Gaussian 03 program $^{41}$ on a 34-processors IBM Linux computer cluster in our lab. The electronic wave functions calculated at the $\mathrm{HF} /$ 6-31G* level were used to derive possibly useful electronic structure-based molecular descriptors. such as molecular dipole moments. net atomic charges. and energies of the highest occupied molecular orbital (HOMO) and the lowest unoccupied molecular orbital (LUMO).

Acknowledgement. This study was supported by research funds from Chosun University. 2005

\section{References}

1. Foye. M. O. Cancer Chemotherapentic Agents. American Chemical Society: Washington. D. C.. 1995: p 203.

2. Liu. L. F.: Row. T. C.: Yang. L. J. Biol Chem. 1984. 259.9182

3. Leopold. W. R.: Shillis. J. L.: Mertus. A. E.: Nelson. J. M.: Roberts. B. J.: Jackson. R. C. Cancer Res. 1984. H. 1928.

4. Scheithauer. W. Von Hoff̈. D. D.; Clark. G. M.: Shillis. I. L.: Elslager. E. F. Em. J. Cancer (Chin. Oncol 1986. 22.921.

5. Ting. C. Y.: Hsu. C. T.: Su J. S: Chen. T. Y: Tam, W. Y.: Kulo. Y H.: Whang-Peng. J.: Liu. L. F.: Hwang. J. Biochem. Pharmacol. 2003. 66. 1981

6. Song. G. Y.: Kim. Y: You. Y. J.: Cho. H.: Kim. S. H.: Sok. D. E.: Ahn, B. Z. Arch. Pham. Pharm. Hed Chem. 2000. 333, 87.

7. Chae, G. H. Song G. Y: Kim, Y. Cho. H.: Sok: D. E.: Alnt. B. Z. Arch. Pham Res. 1999. 22, 507.

8. Song. G. Y.: Kim. Y.: Zheng. X. G: You. Y. J.: Cho. H.: Chung. J. H.: Sok. D. E.: Ahn. B. Z. Eur. J. Hed Chem. 2000. 35.291.

9. Song. G. Y.: Zheng. X. G.: Kim. Y.: You. Y. J.: Sok. D. E.: Ahn. B. Z. Bioorg. Hed. Chem. Lett 1999, 9. 2407.

10. Kim, Y.: You, Y. J: Alnt. B. Z. Arch. Pham. Pham Med Chem. $2001,33+, 318$

11. Lown. J. W.: Sim. S. K.: Majumdar. K. C.: Chang. R. Y. Biochem. Biophys. Res. Commun. 1977. 76.705.

12. Tewey, K. M.: Chen. G. L.: Nelson. E. M.: Liu. L. F. J. Biol. Chem. 1984, 259.9182.

13. Hertzberg. R. P: Dertan. P. B. Biochemishy 1984, 23.3934

14. Silverman. R. B. The Organic Chentistry of Drig Design and Dring Action: Academic Press: New York. 1992: pp 255-258.

15. Inbaraj. J. J.: Chignell. C. F. Chent. Res. Toxicol. 2004. 17. 55.

16. Huang. S. T.: Kuo. H. S.: Hsiao. C. L.: Lin. Y. L. Bioorg. Med. Chem. 2002, 10. 1947

17. Tandon. V. K.: Chhor. R. B.: Singh. R. V: Rai, S.: Yadav, D. B.
Bioorg. Med. Chem. Lett. 2004. 1t, 1079

8. Sasaki. K.: Abe. H.: Yoshizaki. F. Biol. Pharnt. Bull. 2002. 25. 669.

19. Lien. J. C.: Huang. L. J.: Teng. C. M.: Wang. I. P.: Kuo. S. C Chem. Pham. Bull. 2002. 50.672.

20. Huang. L. J.: Chang. F. C. Lee. K. H.: Wang. J. P.; Teng, C. M. Kuo. S. C. Bioorg ifed Chem 1998. 6, 2261

21. Lien. J. C.: Huang. L. I.: Wang. T. P.: Teng. C. M.: Lee. K. H.: Kuo. S. C. Chent. Pharnt. Bull. 1996. H. 1181

22. Lien. J. C.: Huang. L. J.: Teng. C. M.: Wang. T. P.: Kuo. S. C Chem. Pham Bull 2002. 50.672 .

23. Jin, Y. R.: Ryu, C. K:: Moon, C. K.: Cho. M. R.: Yun. Y. P Phamacolog, 2004. 70, 195 .

24. Yuk. D. Y.: Ryu. C. K.: Hong. T. T.: Chung. K. H.: Kang. W. S. Kim. Y: Yoo. H. S.: Lee. M. K.: Lee. C. K.: Yun1. Y. P. Biochent. Pharnacol. 2000. 60. 1001

25. Zhang. Y. H.; Chung. K. H.: Ryu. C. K.: Ko, M. H.: Lee. M. K.; Yun. Y. P. Biol. Pham Bull. 2001. 24,618.

26. Ishiguro, K.: Oku, H. Foods Food lngedients J. Jpn. 2004. 209. 13

27. Kimn. H. J.: Kang. S. K.: Mun. J. Y.: Chun. Y. J.: Choi. K. H.: Kim. M. Y. FEBS Lett. 2003. 555.217.

28. Kim. H. J.: Mun. J. Y; Chun, Y. J.: Choi. K. H.; Ham, S. W.: Kim. M. Y. Arch. Phamacal Res. 2003. 26. 405.

29. Gao. D.: Hiromura, M.; Yasui, H.; Sakurai, H. Biol. Pham Bull 2002. 25. 827

30. Richwiet1. A.: Wurm. G. Pharntazie 2004. 59. 163

31. Wumm. G.: Schwandt. S. Pharnazie 2003. 58.531

32. Ravelo. A. G.; Estevez-Braun, A.: Chavez-Orellana. H.; PerezSacau. E.: Mesa-Siverio. D. Com: Top. Med Chem 2004, f, 241

33. Cho. H. Chung, Y. Korean J. of Med Chem 1998. 8,30 .

34. Chung. Y. S.; Im. J. K.; Lee, S. D.; Cho. H. Bull Kowan Chem Soc. 2004. 20. 1408

35. Chung. Y. S.: Shin. Y. K.: Zhan. C. G.: Lee. S. D.: Cho. H. Arch of Pharnt. Rex 2004. 27.893.

36. Kim. B. H; Yoo. J.: Park. S. H.: Cho, H.: Chung, Y. Arch of Pham Res. 2005, 29(2), 123.

37. (a) Benthey: W. H.: Robinson, R. Weizmann. C. J. Chem Soc 1907. 104. (b) Carter. A. H.: Race. E.: Rowe. F. M. J. Chen. Soc 1942. 236. (c) Zweig. A.: Maurer. A. H.: Roberts. B. G. J. Org. Chent 1967. 32, 1332. (d) Bacon. R. G. R.: Rennison. S. C. J. Chem. Soc./C) 1969. 312. (e) Hansch. C.: Maloney. P. P.: Fujita. T.: Muir. R. M. Nature 1962. 194. 178.

38. Carmichael. J.: DeGraffi. W. G.: Gazdr. A. F.: Minna. J. D.: Mitchelle. I. B. Cancer Res. 1987. 77.936

39. Q'Brien. P. T. Chen Biol Interact 1991. 80 . I

40. Hehre. W. T.: Radom. L.: Schleyer. P. V. R.: Pople. T. A. Ab Initio Iolecular Orbital Theory: John Wilev \& Sons: New York. 1987

41. Frisch. M. J.: Trucks. G. W: Schlegel. H. B.: Scuseria, G. E. Robb. M. A.: Cheeseman. J. R.: Montgomery. Jr., J. A.; Vreven. T.: Kudin. K. N.: Burant. T. C.: Millam. T. M.: Iyengar. S. S.: Tomasi. I.: Barone. V: Mennucei. B.: Cossi. M.: Scalmani. G.: Rega. N.: Petersson1. G. A.: Nakatsuji. H.: Hada. M.: Ehara. M.: Tovota, K, Fukuda, R: Hasegawa, J.; Ishida. M.: Nakajima. T: Honda. Y, Kitao. O.: Nakai. H.; Klene, M.; Li, X: Knox. J. E.; Hratchian, H. P: Cross, J. B.; Adamo. C.: Jaramillo. J.: Gomperts. R: Stratmantr. R. E:: Yazyey. O: Austin. A. J: Cammi. R.: Pomelli. C.: Ochterski. I. W.: Avala. P. Y.: Morokuma. K.: Voth. G. A.: Salvador. P.: Darnentherg. J. T.: Zakrzewski. V. G.: Dapprich. S.: Daniels, A. D.: Strain, M. C.: Farkas, O.; Malick, D. K.: Rabuck. A. D.: Raghavachari, K.; Foresman, J. B.; Ortiz. J. V: Cui. Q: Baboul, A. G.; Clifford. S.: Cioslowski. J.; Stefanov. B. B.: Liu. G.: Liashenko. A.: Piskorz. P.: Komaromi. I.: Martitl. R. L.: Fox. D. T.: Keith. I.: Al-Laham. M. A.: Peng. C. Y: Nanayakkara. A.: Challacombe M.: Gill. P. M. W: John1sont. B.: Chen. W: Wong. M. W.: Gonzalez. C: Pople, J. A. Gaussian 03. Revision A. I; Gaussian. Inc.: Pittsburgh. PA, 2003. 